\title{
EFFICACY OF TALAROMYCES FLAVUS COATED WITH NANOPARTICLES IN THE GROWTH INHIBITORY OF FUSARIUM OXYSPORUM F.SP. CUCUMERINUM
}

\author{
Laleh Naraghi \\ Iranian Research Institute of Plant Protection, Agricultural Research, \\ Education and Extension Organization (AREEO), Tehran, (Iran). \\ E-mail: lale_naraghi@yahoo.com ORCID: https://orcid.org/0000-0001-5767-2498 \\ Maryam Negahban \\ Iranian Research Institute of Plant Protection, Agricultural Research, \\ Education and Extension Organization (AREEO), Tehran, (Iran). \\ E-mail: mnegahban2009@gmail.com ORCID: https://orcid.org/0000-0002-6602-9936
}

Recepción: 08/01/2020 Aceptación: 19/02/2020 Publicación: 13/03/2020

Citación sugerida:

Naraghi, L., y Negahban, M. (2020). Efficacy of Talaromyces Flavus coated with nanoparticles in the growth inhibitory of Fusarium Oxysporum F.SP. Gucumerinum. 3C Tecnología. Glosas de innovación aplicadas a la pyme, 9(1), 31-45. http:// doi.org/10.17993/3ctecno/2020.v9n1e33.31-45 


\section{ABSTRACT}

In this study, nanobioformulations were prepared containing the fungus Talaromyces flavus including two types of nano-capsules (F1 and F3), one type of nanoemulsion (F2), and one type of powdered nanoformulation (F4). Comparative in vitro studies were performed on nanoformulations and formulations made based on rice bran from T. flavus in terms of inhibitory effect on the colony growth the pathogenic fungus Fusarium oxysporum f. sp. cucumerinum in a completely randomized design. These studies began three months after the production of nanoformulations and continued at 3 months intervals for one year. The results showed that the nanopowder was the most effective nanoformulation in increasing the inhibitory effect on the growth of the examined pathogen.

\section{KEYWORDS}

Nanoformulation, Talaromyces flavus, Biological control, Plant pathogens. 


\section{INTRODUCTION}

Studies conducted in Iran have demonstrated favorable results of the antagonist fungus, Talaromyces flavus, for the control of some important pathogenic pathogens such as Verticillium dahliae, Verticillium albo-atrum, Fusarium oxysporum, and Rhizoctonia solani in some crop varieties including cotton, sugar beet, potatoes, tomatoes, and greenhouse cucumbers (Naraghi et al., 2010a; Naraghi et al., 2010b; Naraghi et al., 2010c).

Also, the application of this fungus as solid fermentation in the field on plant residues or their mixture with peat soil reduced the incidence of disease and increased the yield of the above-mentioned crops. Reduction of Verticillium wilt (50\%), reduction in seedling death rate $(37 \%)$, and $30 \%$ increase in yield were found in cotton plant, and 40\% decrease in disease percentage and $17 \%$ yield increase were reported in potato plant (Naraghi et al., 2014b). A 93\% increase in the number of healthy seedlings and a 50\% increase in yield were observed in sugar beet plants (Naraghi et al., 2014a). A 27\% decrease in disease severity and a $23 \%$ rise in yield were noticed in tomato (Niya et al., 2015). And a 30\% reduction of disease severity and a 7\% yield increase were achieved in greenhouse cucumber (Naraghi et al., 2017). Since marketing and attracting consumers are considered as important issuesin mass production and commercialization of biological agents (Husen et al., 2006; Alimi et al., 2006; Kaewchai, Soytong, \& Hyde, 2009; Pereira et al., 2009), the commercialization of T. flavusas a biological agent and the importance of producing its various bioformulations, including nanoformulations, seem to be necessary at present time.

In recent decades, nanotechnology has expanded dramatically in various fields of chemistry, pharmacology, medicine, and agricultural chemical pesticides. The phenomenon of pest resistance to pesticides is an issue that necessitates research and development in the field of nano-pesticides. Therefore, the introduction of nano-pesticides to researchers will flourish in research and development in this field. The environmental problems, costs of consuming large quantities of conventional pesticides, and the problems caused by pest resistance to these pesticides raise the necessity of research and development in the field of nano-pesticides. 
The use of biodegradable polymers in the production of high-performance nanoemulsions and nanocapsules made of natural and biodegradable materials can be an effective step in this regard. To increase efficacy and reduce environmental hazards, encapsulation formulation seems to be the best option (Maji et al., 2014). Therefore, the production of nano and micro bioformulation creates controlled ability, increased strength and stability, and protection of active ingredients under adverse environmental conditions such as light and moisture. The use of nanocapsulated formulation also helps remarkably in cost reduction of pesticide consumption dose, economic benefit, protection of the environment, and reduction of its environmental risks, and better export of the crop (Martín et al., 2010).

Nanoparticles have a larger surface area than the microparticles, which increases their active surface area and controlled release. Moreover, another advantage of nanometer particles is that they do not stimulate the immune system of humans and animals, and rapidly exit the body (Guan et al., 2008).

The technology of nanocapsules containing nano-scale fungicide or pesticide molecules is a method of pesticide formulation that facilitates and accelerates pest elimination (Guan et al., 2008). An emulsion is a heterogeneous system consisting of two immiscible liquids, one of which is dispersed as droplets in the other. Emulsions with a droplet size of about nanometers, typically in the range of 1-2 nm, are called nanoemulsions (Ostertag, Weiss, \& McClements, 2012). Compared with conventional emulsions, the unique structure and properties of nano-emulsions have provided advantages for their application in many industries. Industrial applications of nano-emulsion systems include their role in the elimination of the coating and controlled release of beneficial compounds such as essential oils, vitamins, and so forth (Kah \& Hofmann, 2014). 


\section{METHODS}

\subsection{IN VITRO EXAMINATIONS}

\subsubsection{PRODUCTION OF NANOCAPSULES CONTAINING THE BIOLOGICAL FUNGUS TALAROMYCES FLAVUS}

The production of nanocapsules combines polymerization and lattice formation. It was performed through modifications matching the biological fungal growth conditions (changing the amount or type of polymer, surfactants, and oils, fatty acids, stirrer speed, and temperature). In the polymerization process, the organic phase consisted of vegetable oil with a mixture of the biological fungus, which was added to the aqueous phase consisting of hydrophilic polymeric monomers, such as a mixture of either formaldehyde or alginate polymers, starch, and chitosan. Then, such cross-linkers as calcium chloride, surfactants and associated materials, and fatty acid oils were added to the two phases and homogenized with a homogenizer (5000-10,000 rpm) at $35^{\circ} \mathrm{C}$. Finally, lattice polymer particles were encapsulated around the particle's biological fungus.

\subsubsection{PRODUCTION OF NANOEMULSIONS CONTAINING THE BIOLOGICAL FUNGUS T. FLAVUS}

A self-assemble model was used to prepare nanoemulsions containing the biological fungus T. flavus. Finally, a nanoemulsion was formulated containing hydrophobic nanoparticles of vegetable oil in a biocompatible formulation. Components of this formulation were active ingredients of the biological fungus and vegetable oils (e.g. hydrophobic castor oil), twin surfactant, viscose materials of carboxymethyl cellulose, coconut moisturizer, fatty acid ethanol amide, and polyvinyl acetate stabilizer (e.g. alcohol polyvinyl), linkers (e.g. calcium chloride), and biocompatible polymers (e.g. ethylene glycol, and starch). First, a homogeneous solution of biocompatible polymers was prepared, followed by the addition of such surfactants as a tween and the associated materials to the solution. A completely homogeneous mixture of polymer and solvent was prepared using a homogenizer (2000-12000 rpm) at $25^{\circ} \mathrm{C}$. Then, 
the suspension containing the spores of biological fungus was added drop wise together with castor oil and coconut fatty acids. Next, a cross-linker (calcium chloride) was added to both the two phases to form nanoparticles around the biological fungal spores. Finally, the nanoparticles were coated around the biological fungal spores.

\subsubsection{PRODUCTION OF NANOPOWDERS CONTAINING THE BIOLOGICAL FUNGUS T. FLAVUS}

The suspension containing biological fungal spores was dispersed in the aqueous phase including maltodextrin, xanthan gum, methyl xanthan, fatty acid ethanolamide, and oleic acid. It was then fully powdered in a homogenizer (2000-12000 rpm) at $25^{\circ} \mathrm{C}$.

\subsubsection{COMPARISON OF GROWTH INHIBITORY EFFICIENCIES OF DIFFERENT NANOFORMULATIONS CONTAINING T. FLAVUS AGAINST FUSARIUM WILT PATHOGEN IN GREENHOUSE CUCUMBERS}

The efficiencies of different T. flavus nanoformulations for growth inhibition of soil pathogen $(F$. oxysporum f. Sp. cucumerinum: FOC) were evaluated in a completely randomized design three months after production and continued at three-month intervals for one year. To investigate each nanoformulation, a petri dish containing the PDA medium was subdivided into two halves using an assumed line. A $0.5 \mathrm{~mm}$ piece of the pathogen was placed by a cork borer in one half and the other half received $0.1 \mathrm{~g}$ of a nanoformulation. Each of the afore mentioned pathogens was examined separately in a completely randomized design with five treatments (four new and control nanoformulations) in three replications. For the control petri dish, the pathogen fragment was placed in only half of the petri dish. The colony diameter was measured in the treatment and control 7 days after placement of the pathogen and formulation on the petri dish to determine the inhibition percentage for each studied pathogen by the nanoformulation, which was calculated using the following formula:

Inhibition percentage $=\mathrm{D}_{\mathrm{t}}-\mathrm{D}_{\mathrm{c}} / \mathrm{D}_{\mathrm{c}} \times 100$, where $\mathrm{D}_{\mathrm{t}}$ and $\mathrm{D}_{\mathrm{c}}$ are the growth diameters of pathogen colonies in the treatment and the control, respectively. 
Data analysis and comparison of mean growth inhibition percentages of pathogen colonies by the nanoformulation were performed by Duncan's multiple range test using the MS TAT C software.

The pathogen, F. oxysporum f. sp. cucumerinum studied here was confirmed earlier in terms of pathogenicity, which was obtained from the collection of the research laboratory for useful microorganisms in the Iranian Institute of Botanical Research.

\section{RESULTS}

\subsection{QUALITATIVE AND QUANTITATIVE INTRODUCTION OF COMPOUNDS USED IN $100 \mathrm{G}$ OF PREPARED NANOFORMULATIONS}

Four nanoformulations, namely two types of nanocapsules, one type of nanoemulsion, and one type of nanopowderswere produced in this study (Figure 4), and the compounds used in $100 \mathrm{~g}$ of the nanocapsulesare shown qualitatively and quantitatively in (Table 1).
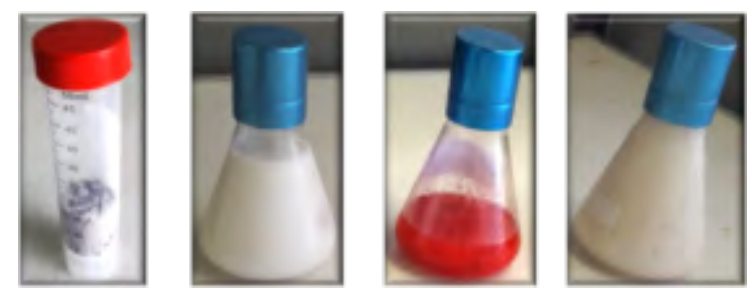

Figure 1. The prepared nanoformulations (right toleft): Nanocapsules 1 (F1), Nanoemulsions (F2), Nanocapsules 2 (F3), and Nanopowders (F4).

The biological fungus was prepared using T. flavus suspension with a concentration of 10 spores $/ \mathrm{ml}$.

**Because the nano-formulations were prepared under non-sterile conditions, butanol was used to prevent bacterial and fungal contamination in the evaluation of the nano-formulation efficacies in growth inhibition of the fungal pathogen. 
Table 1. The types of prepared nanoformulations and the amounts of compounds used in $100 \mathrm{~g}$ of each nanoformulation type.

\begin{tabular}{|c|c|c|c|c|c|c|c|}
\hline \multicolumn{8}{|c|}{ Types of nanoformulations prepared and the number of compounds used in $\mathbf{1 0 0}$ grams of each nanoformulation } \\
\hline \multicolumn{2}{|c|}{ Nanocapsules 1 (F1) } & \multicolumn{2}{|c|}{ Nanoemulsions (F2) } & \multicolumn{2}{|c|}{ Nanocapsules 2 (F3) } & \multicolumn{2}{|c|}{ Nanopowders (F4) } \\
\hline Compound & $\begin{array}{l}\text { Amount } \\
\text { (g) }\end{array}$ & Compound & $\begin{array}{l}\text { Amount } \\
\text { (g) }\end{array}$ & Compound & $\begin{array}{l}\text { Amount } \\
\text { (g) }\end{array}$ & Compound & $\begin{array}{c}\text { Amount } \\
\text { (g) }\end{array}$ \\
\hline $\begin{array}{l}\text { Biological } \\
\text { fungus * }\end{array}$ & 19 & $\begin{array}{l}\text { Biological } \\
\text { fungus * }\end{array}$ & 35 & $\begin{array}{l}\text { Biological } \\
\text { fungus * }\end{array}$ & 53 & $\underset{*}{\text { Biological fungus }}$ & 5 \\
\hline Alginate & 8 & Lauryl alcohol & 5.17 & Urea & 9 & Maltodextrin & 5.14 \\
\hline Castor oil & 16 & Castor oil & 9 & Castor oil & 5.4 & Castor oil & 5.33 \\
\hline $\begin{array}{l}\text { Coconut fatty } \\
\text { acids }\end{array}$ & 32 & $\begin{array}{l}\text { Coconut fatty } \\
\text { acids }\end{array}$ & 5.17 & $\begin{array}{l}\text { Coconut fatty } \\
\text { acids }\end{array}$ & 5.4 & $\begin{array}{c}\text { Fatty acid ) } \\
\text { diethanolamide - } \\
\text { Oleic acid( }\end{array}$ & 5.8 \\
\hline \multirow{2}{*}{$\begin{array}{l}\text { Sodium } \\
\text { chloride }\end{array}$} & \multirow[t]{2}{*}{2} & $\begin{array}{c}\text { Sodium } \\
\text { chloride } 1.0 \\
\%\end{array}$ & 2 & $\begin{array}{l}\text { Sodium } \\
\text { chloride } 1.0 \%\end{array}$ & 2 & \multirow{2}{*}{ Xanthangam } & \multirow[t]{2}{*}{5.8} \\
\hline & & $\begin{array}{l}\text { Twin } \\
\text { surfactant }\end{array}$ & 4 & Twin surfactant & 4 & & \\
\hline $\begin{array}{l}\text { Polyethylene } \\
\text { glycol }\end{array}$ & 20 & $\begin{array}{l}\text { Polyethylene } \\
\text { glycol }\end{array}$ & 12 & Formaldehyde & 5.18 & - & - \\
\hline Butanol $^{* *}$ & 3 & Butanol & 3 & Butanol & 3 & Butanol & 3 \\
\hline
\end{tabular}

*For preparation of biologic fungi, suspension of Talaromyces flavus with concentration of $10^{9}$ spore per liter was used. ** Due to the preparation of nanoformulation in non-sterile conditions, butanol was used to prevent bacterial and fungal contamination to evaluate the efficacy of nanoformulation in inhibiting the growth of the disease agent.

\subsection{COMPARISON OF GROWTH INHIBITORY EFFICIENCIES OF DIFFERENT NANOFORMULATIONS CONTAINING T. FLAVUS AGAINST FOC}

In the first and the second trimester after production, the efficiency of nanoformulation in inhibition of FOC colony growth (Figure 2) and (Figure 3) decreased from the first to the second trimester in all nanoformulations (Table 2). From the third trimester, the inhibition was only observed for nanopowders on FOC colony growth (Figure 4 and Table 2). The efficacies of different nanoformulations in inhibition of FOC colony growth were significant in the first, second, third, and fourth trimesters after production at a $1 \%$ probability level. 
In the first trimester of production, a comparison of average FOC colony growth inhibition of each formulation revealed that the formulations were in two statistical groups, with nanocapsule 1, nanoemulsions, and nanopowders being most effective in terms of inhibition level (Table 2). Comparison of FOC inhibition averages from each formulation in the second trimester also indicated that the formulations were in two statistical groups and nanopowder and nanocapsule 2 nanoformulations presented the highest efficacy in growth inhibition of FOC colony (Table 2). The third and fourthtrimester comparisons of FOG inhibition averages represented that the formulations were also in two statistical groups and only an inhibition effect on FOC colon growth was observed only in the nanopowders in these periods (Table 2).

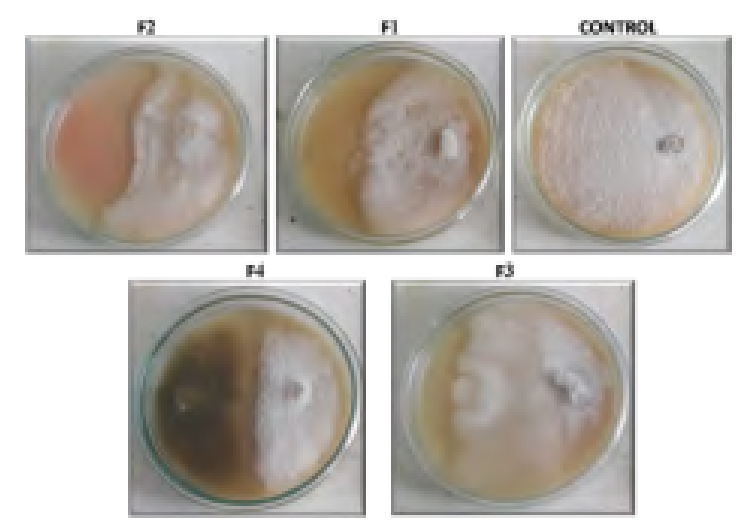

Figure 2. Growth inhibition rate of Fusarium oxysporum f. sp. cucumerinum by different nanoformulations on PDA media in the first trimester after production. CONTROL, F1 (nanocapsule 1), F2 (nanoemulsion), F3 (nanocapsule 2), and F4 (nanopowder). 

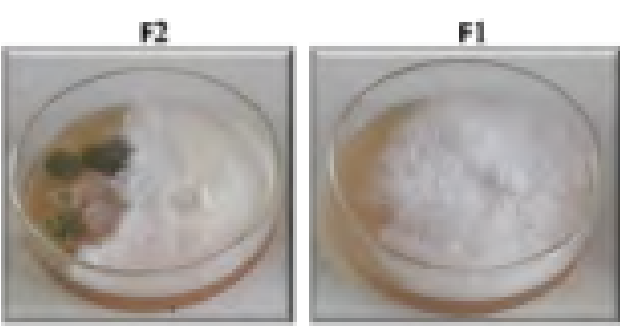

F4
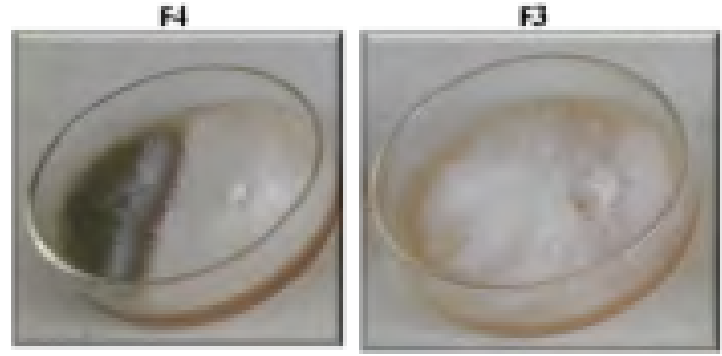

Figure 3. Growth inhibition rate of Fusarium oxysporum f. sp. cucumerinu by different nanoformulations on PDA medium in the second trimester after production. CONTROL,F1 (nanocapsule 1), F2 (nanoemulsion), F3 (nanocapsule 2), and F4 (nanopowder).

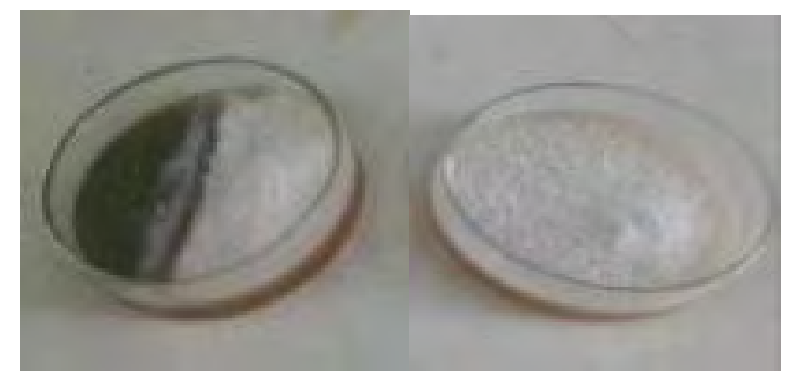

Figure 4. Growth inhibition of Fusarium oxysporum f. sp. cucumerinumcolony growth by the nanopowder (right) compared with the control (left) in the fourth trimester after production. 
Table 2. Comparison of mean growth inhibition rates of Fusarium oxysporum f. sp. cucumerinum (FOC) in different nanoformulation treatments.

\begin{tabular}{|c|c|c|c|c|}
\hline \multirow[b]{2}{*}{ Formulation } & \multicolumn{4}{|c|}{ Mean FOC growth inhibition (\%) } \\
\hline & $\begin{array}{c}1^{\text {st }} \\
\text { trimester }\end{array}$ & $\begin{array}{c}2^{\text {nd }} \\
\text { trimester }\end{array}$ & $\begin{array}{c}3^{\text {rd }} \\
\text { trimester }\end{array}$ & $\mathbf{4}^{\text {th }}$ \\
\hline F1(Nanocapsule 1-polyalginate) & a25.31 & $\mathrm{c} 00 \cdot 10$ & b0 & b0 \\
\hline $\begin{array}{c}\text { F2 (Nanoemulsion-polyethylene } \\
\text { glycol) }\end{array}$ & $a b 12 \cdot 26$ & bc44.14 & b0 & b0 \\
\hline $\begin{array}{c}\text { F3 (Nanocapsule 2-polyurea } \\
\text { formaldehyde) }\end{array}$ & b00.20 & $a b 61 \cdot 16$ & b0 & b0 \\
\hline $\begin{array}{c}\text { F4 (Nanopowder-maltodextrin, } \\
\text { xanthan gum) }\end{array}$ & a77.27 & a42.21 & $\mathrm{a} 00 \cdot 24$ & $\mathrm{a} 42 \cdot 20$ \\
\hline $\begin{array}{l}\text { Without nanoformulation } \\
\text { (control) }\end{array}$ & - & - & - & - \\
\hline
\end{tabular}

*Means with similar letters are not significantly different at $1 \%$ probability level.

${ }^{* *}$ The inhibition rate of the pathogen colony growth in nanoformulation treatments was compared to the without nano-formulation (control) and no inhibition was observed in the control.

\section{DISCUSSION}

Overall, the present results showed that the nanopowder had the uppermost efficiency among the prepared nanoformulations (two types of nanocapsules, nanoemulsions, and nanopowders) in terms of Fusarium wilt growth inhibition. The results obtained from the effect of prepared nanoformulations on the growth of some plant pathogens are in line with those of previous research (Khan \& Jameel, 2016) on the inhibitory effect of a nanoformulation containing Penicillium fellutanum on Candida albicans. The in vitro study observed inhibition zones of the pathogenic fungal growth in petri dishes around nanoformulation tablets.

Naratghi et al. (2012) reported that some mechanisms play a more effective role in different plant pathogens than other mechanisms. For example, the above study found that mycoparasitism was the most effective mechanism for Fusarium growth inhibition. On the other hand, the effective metabolites of 
the production mechanisms of non-volatile compounds and mycoparasitism were reported to be glucose oxidase and chitinase, respectively (Kim, Fravel, \& Papavizas, 1990; Inbar \& Chet, 1995) and levels of these metabolites and their activity to be variable depending on time and environmental conditions (Zhai et al., 2016). Thus, the effects of different nano compounds cannot be ignored on the amount and intensity of different T. flavus metabolites. In the present study, the time and environmental conditions in the second trimester were likely such that the intensity and activity of the Fusarium effective metabolite (chitinase) were lower than those of other T. flavus metabolites present in the nanoformulation.

\section{REFERENCES}

Alimi, T., Ajewole, O. G., Olubode-Awosola, O. O., \& Idowu, E. O. (2006). Economic rationale of commercial organic fertilizer technology in vegetable production in Osun State of Nigeria. Fournal of Applied Horticulture, 8(2), 159-164. http://horticultureresearch.net/pdf/Economic\%20 rationale $\% 20$ of\%20commercial $\% 20$ organic $\% 20$ fertilizer $\% 20$ technology $\% 20$ in $\% 20$ vegetable \%20production.pdf

Guan, H., Ghi, D., Yu, J., \& Li, X. (2008). A novel photodegradable insecticide: Preparation, characterization and properties evaluation of nano-Imidacloprid. Pesticide Biochemistry and Physiology, 92(2), 83-91. https://doi.org/10.1016/j.pestbp.2008.06.008

Husen, E., Simanungkalit, R. D. M., Suraswati, R., \& Irawan, I. (2007). Characterization and quality assessment of Indonesian commercial biofertilizer. Indonesian Fournal of Agricultural Science, 8(1), 31-38. http://dx.doi.org/10.21082/ijas.v8n1.2007.p31-38

Inbar, J., \& Chet, I. (1995). The role of recognition in the induction of specific chitinases during mycoparasitism. Microbiology, 141(11), 2823-2829. https://doi.org/10.1099/13500872-141-112823 
Kaewchai, S., Soytong, K., \& Hyde, K. D. (2009). Mycofungicides and fungal biofertilizers. Fungal Diversity, 38, 25-50. https://www.researchgate.net/publication/235930122_Mycofungicides_ and_fungal_biofertilizers

Kah, M., \& Hofmann, T. (2014). Nanopesticide research: current trends and future priorities. Environment international, 63, 224-235. https://doi.org/10.1016/j.envint.2013.11.015

Khan, N. T., \& Jameel, N. (2016). Antifungal activity of silver nanoparticles produced from fungus, Penicillium fellutanum at different pH. Fournal of Microbial and Biochemical Technology, 8(5), 440-443. https://doi.org/10.4172/1948-5948.1000322

Kim, K. K. A., Fravel, D. R., \& Papavizas, G. G. (1990). Glucose oxidase as the antifungal principle of talaron from Talaromyces flavus. Canadian Fournal of Microbiology, 36(11), 760-764. https://doi. org/10.1139/m90-131

Maji, R., Dey, N. S., Satapathy, B. S., Mukherjee, B., \& Mondal, S. (2014). Preparation and characterization of Tamoxifen citrate loaded nanoparticles for breast cancer therapy. International Journal of Nanomedicine, 9(1), 3107-3118. https://doi.org/10.2147/IJN.S63535

Margulis-Goshen, K., \& Magdassi, S. (2013). Nanotechnology: an advanced approach to the development of potent insecticides. In Ishaaya I., Palli S., Horowitz A. (eds) Advanced Technologies for Managing Insect Pests. Springer. https:/ / doi.org/10.1007/978-94-007-4497-4_15

Martín, A., Varona, S., Navarrete, A., \& Cocero, M. J. (2010). Encapsulation and co-precipitation processes with supercritical fluids: applications with essential oils. The Open Chemical Engineering Journal, 4(1), 31-41. https://doi.org/10.2174/1874123101004010031 
Naraghi, L., Arjmandian, A., Heydari, A., Sharifi, K., \& Azad, H. A. (2014a). A comparison between carbendazim fungicide and Talaromyces flavus in controlling Verticillium wilt of potato under field conditions. International Fournal of Agricultural Science and Research, 4(1), 89-100. http:// www.tjprc.org/publishpapers/--1400077175-absA\%20COMPARISON\%20BETWEEN\%20 CARBENDAZIM\%20FUNGICIDE\%20AND.pdf

Naraghi, L., Heydari, A., Afshari Azad, H., \& Sharifi, K. (2012). Antagonistic effects of Talaromyces flavus on some soil-borne pathogens of potato, tomato and greenhouse cucumber. Proceedings of $20^{\text {th }}$ Iranian Plant Protection Congress, 278 p.

Naraghi, L., Heydari, A., Hesan, A., \& Sharifi, K. (2014b). Evaluation of Talaromyces flavus and Trichoderma harzianum in biological control of sugar beet damping-off disease in the greenhouse and field conditions. International Fournal of Agricultural Science and Research, 4(1), 65-74. https: / / www. academia.edu/5819295/Evaluation_of_Talaromyces_flavus_and_Trichoderma_harzianum_ in_Biological_Control_of_Sugar_Beet_Damping-off_Disease_in_the_Greenhouse_and_Field_ Conditions

Naraghi, L., Heydari, A., Rezaee, S., Razavi, M., \& Afshari-Azad, H. (2010a). Biological control of greenhouse cucumber Verticillium wilt disease by Talaromyces flavus. Phytopathologia Mediterranea, 49(3), 321-329. www.jstor.org/stable/26458657

Naraghi, L., Heydari, A., Rezaee, S., Razavi, M., \& Jahanifar, H. (2010b). Study on antagonistic effects of Talaromyces flavus on Verticillium albo-atrum, the causal agent of potato wilt disease. Crop Protection, 29(7),658-662. https://doi.org/10.1016/j.cropro.2010.01.011

Naraghi, L., Heydari, A., Rezaee, S., Razavi, M., Jahanifar, H., \& Mahmoodi Khaledi, E. (2010c). Biological control of tomato Verticillium wilt disease by Talaromyces flavus. Fournal of Plant Protection Research, 50(3), 360-365. https://doi.org/10.2478/v10045-010-0061-x 
Naraghi, L., Shahriary, D., Sarpeleh, A., \& Afshari Azad, H. (2017). Decrease in incidence of cucumber Fusarium wilt in Varamin greenhouse using Talaromyces flavus. International fournal of Agricultural Science and Research, 7(4), 143-154. https://doi.org/10.24247/ijasraug201719

Niya, S. F., Naraghi, L., Ommati, F., \& Pirnia, M. (2015). Evaluation of the efficacy of the biological compound affected by Talaromyces flavus in controlling tomato Fusarium wilt disease in the field conditions. International Fournal of Agricultural Science and Research, 5(2), 153-164. https://www.academia.edu/27580744/EVALUATION_OF_THE_EFFICACY_OF_ THE_BIOLOGICAL_COMPOUND_AFFEGTED_BY_TALAROMYGES_FLAVUS_ IN_GONTROLLING_TOMATO_FUSARIUM_WILT_DISEASE_IN_THE_FIELD_ GONDITIONS

Ostertag, F., Weiss, J., \& McGlements, D. J. (2012). Low-energy formation of edible nanoemulsions: factors influencing droplet size produced by emulsion phase inversion. Fournal of Colloid and Interface Science, 388(1), 95-112. https://doi.org/10.1016/j.jcis.2012.07.089

Pereira, I., Ortegu, R., Barrientus, L., Moya, M., Reyes, G., \& Kramm, V. (2009). Development of a biofertilizer based on filamentous nitrogen- fixing cyanobacteria for rice crops in Chile. Fournal of Applied Phycology, 21(1), 135-414. https://doi.org/10.1007/s10811-008-9342-4

Zhai, M. M., Jang, G. X., Shi, Y. P., Di, D. L., Grews, P., \& Wu, G. (2016). The bioactive secondary metabolites from Talaromyces species. Natural Products and Bioprospecting, 6(1), 1-24. https://doi. org/10.1007/s13659-015-0081-3 